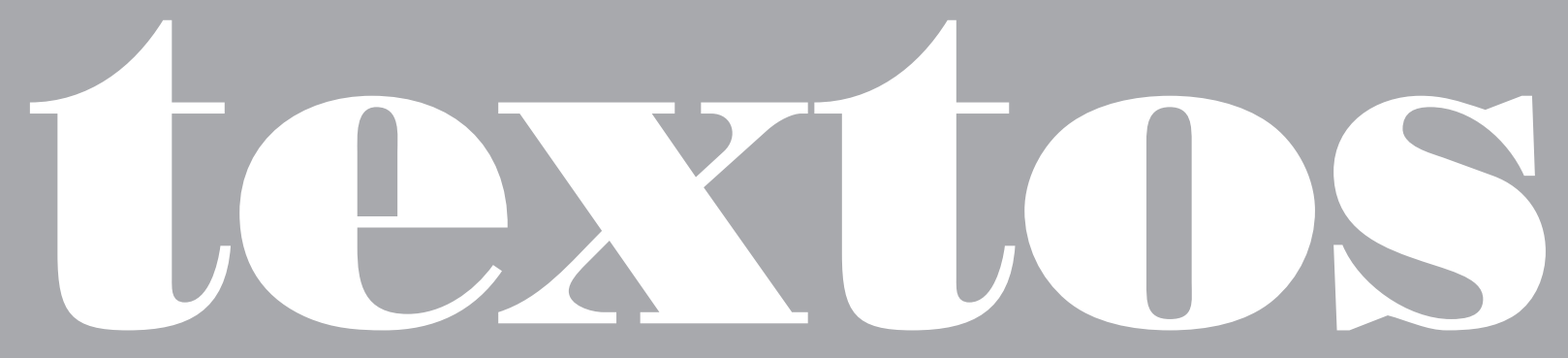





\title{
A patrimonialização do
}

\section{nyau e a redução de sentido}

\author{
Belchior Canivete
}

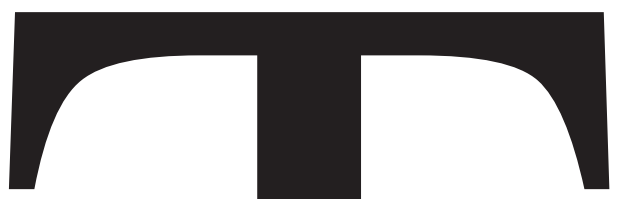

rajano Filho (2010, p. 14) defende que "a ideia de patrimônio não se restringe aos processos oficiais de reconhecimento dos bens culturais como representativos da cultura e da história locais ou nacionais, mas se aplica também aos processos menos formalizados de transformação em 'cultura' de instituições totais”. Esse antropólogo examinou duas associações de ajuda mútua, nomeadamente, as tabancas cabo-verdianas e as mandjuandades guineenses, tendo observado uma mudança na forma como essas associações eram percebidas pelo público externo. No que concerne às tabancas, Trajano Filho afirma que há uma percepção geral de que a sua dimensão de espetáculo tem adquirido uma grande visibilidade, colocando-se em segundo plano os seus aspectos funcionais, rituais e religiosos. Em relação às mandjuandades, o autor aponta que elas gradualmente deixaram de ser percebidas pelo público externo como instituições tradicionais de autoajuda e se transformaram em agrupamentos musicais, dança e divertimento. 
Partindo do argumento de Trajano Filho sobre a pré-patrimonialização das tabancas cabo-verdianas e das mandjuandades guineenses, examino, neste artigo, o processo de transformação do nyau em patrimônio cultural moçambicano e patrimônio oral e intangível da humanidade, procurando observar algumas similaridades ou particularidades entre estes e os processos de pré-patrimonialização das associações de ajuda mútua analisados por Trajano Filho. Argumentarei aqui que, por um lado, o processo de patrimonialização desencadeado pelo novo governo da Frente de Libertação de Moçambique (Frelimo), que vai levar a uma transformação redutora do nyau, está diretamente ligado à construção de uma cultura de caráter nacional e moderna, considerada pela nova elite dirigente como uma questão fundamental para a nova sociedade que se pretende criar. Nesse contexto, o nyau foi ligado ao passado e à história da Frelimo. Defenderei também que o processo de redução do nyau não termina com a sua proclamação pela Organização das Nações Unidas para a Educação, a Ciência e a Cultura (Unesco), em 2005, como obra-prima do patrimônio oral e intangível da humanidade. Contudo, os membros do nyau não são sujeitos passivos nesse processo. Eles estão continuamente negociando os seus interesses nas exposições e nas performances públicas a que são convidados a abrilhantar. Por último, argumentarei no sentido de um nyau multivocal. Para além de uma performance mais voltada para o espetáculo, para uma audiência externa, existe um nyau mais fechado, praticado nos seus locais tradicionais, e que continua a preservar muitos dos valores e costumes do povo chewa.

\section{A DANÇA NYAU EM MOÇAMBIQUE}

Em Moçambique, o nyau é praticado em todas as regiões habitadas pelo povo chewa/nyanja. Mais precisamente, o nyau é dançado em toda a zona planáltica da província de Tete, que compreende os distritos de Angónia, Macanga, Moatize, Chifunde, Zumbo, Tsangano, Marávia e Chiúta; na província da Zambézia, no distrito de Milange; e nos distritos de Mecanhelas, Mandimba e Lago, na província do Niassa.
A dança é praticada pela sociedade dos nyaus, uma sociedade secreta de homens iniciados cuja identidade é escondida pelas máscaras dos ancestrais e de animais ${ }^{1}$. "A máscara significa espíritos contraditórios que se movem entre o homem e as árvores. Elas são esculpidas por um artista que tem o dom para ver tais coisas e sabedoria para sobreviver a elas" (Malawi National Commission for Unesco, 2001, p. 11). O termo nyau é usado também para se referir ao dançarino quando já equipado com as suas vestimentas, isto é, as máscaras e o restante do uniforme. O nyau era dançado sempre no período da noite. Os dançarinos mascarados tradicionalmente se apresentavam com o corpo nu, besuntado de cinza ou lama, e nas suas pernas usavam chocalhos. A atividade principal do nyau parece ser a performance nas cerimônias mais importantes para o povo chewa, nomeadamente, os ritos de iniciação das raparigas, o chinamwali, o funeral, maliro, os ritos de luto, m'bona, e a entronização do chefe. "Apesar de o nyau não constituir a parte principal destas cerimônias, elas fornecem um campo onde possivelmente o nyau assume mais proeminência e importância" (Malawi National Commission for Unesco, 2001, p. 18).

O nyau possui códigos de linguagem, criando assim uma lógica própria que orienta os membros e as suas atividades. Os membros do nyau são responsáveis pela iniciação dos mais jovens na vida adulta. O phungo ${ }^{2}$ determina que o candidato está pronto para a iniciação e comunica aos restantes membros do grupo. A vinculação dos jovens rapazes é feita de forma voluntária, mediante um pagamento feito em espécies ${ }^{3} \mathrm{e}$ em dinheiro, que é usado para as despesas do grupo. Antigamente os membros do nyau batiam nos iniciados com uma vara até sangrar. A passagem por esse "ritual" constituía uma prova de que os candidatos estavam em condições de passar a fazer parte da irmandade e de guardar o segredo do nyau. Esse segredo, que reveste a irmandade nyau de um caráter secreto e místico, parece se

1 Elefantes, búfalos, zebras, rinocerontes, bois, pássaros, entre outros animais.

2 Guia ou guardião.

3 Galinhas, cabritos, porcos, etc. 


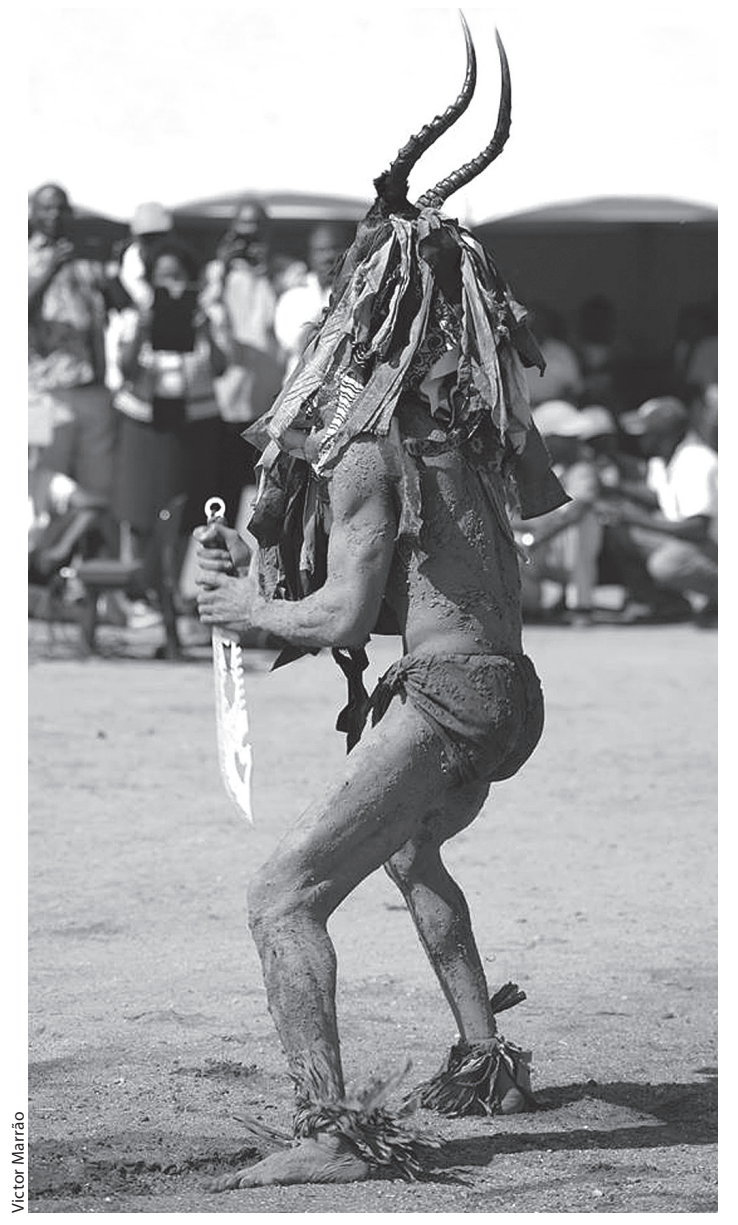

Máscara kampini mostrando a sua bravura com um instrumento cortante

encontrar num cemitério, onde as pessoas têm receio de ir. É lá onde são guardados os fardamentos e as máscaras usadas pelos dançarinos nas suas performances. "O fato é que a coragem para encontrar o cemitério dá um caráter único, quase super-humano" (Malawi National Commission for Unesco, 2001, p. 11).

As sociedades nyau têm uma grande relevância social. Durante as suas performances no chinamwali, os dançarinos do nyau fazem gestos obscenos e proferem palavras insultuosas às noviças. Essa atitude pode ser mais bem explicada pelos conflitos sociais que existem dentro da estrutura matrilinear e uxorilocal dos chewas. Como argumenta Rita-Ferreira (1966 apud Malawi National Commission for Unesco, 2001, p. 27), "o nyau fornece aos homens um certo nível de autoridade que contrabalança o poder das mulheres e das linhagens locais".

\section{O NYAU DURANTE A PRESENÇA COLONIAL PORTUGUESA EM MOÇAMBIQUE}

Em Moçambique, o período 1930-37 foi marcado pela expansão das missões e escolas católicas, que passaram a estar profundamente ligadas aos objetivos sociopolíticos do Estado português. Essa colaboração entre o Estado colonial português e a Igreja Católica foi formalizada em alguns dispositivos, como, por exemplo, o Estatuto das Missões Católicas Portuguesas, a Constituição de 1933, a Concordata e o Acordo Missionário (posteriormente regulamentado pelo Estatuto Missionário). No Estatuto das Missões Católicas Portuguesas, por exemplo, o governo colonial português "manifestou a sua intenção de garantir às missões católicas portuguesas proteção e ajuda do Estado, sob a forma particular de subsídios para a formação de missionários em Portugal e de concessão livre de terrenos" (História de Moçambique, 1999, p. 46). A nova constituição portuguesa de 1933, por seu turno, "reforçou essa política em relação às missões católicas, 'entanto que instituições de educação e instrumentos de civilização"' (História de Moçambique, 1999, p. 46). A Concordata, assinada em 7 de maio de 1940, entre o Estado português e o Vaticano fortaleceu o papel das missões católicas em Moçambique. A partir de 1940-41, a Igreja Católica portuguesa iniciou "uma agressiva campanha de expansão, concorrendo, em condições altamente favoráveis, com as igrejas protestantes. O regime transferiu a responsabilidade do ensino rudimentar oficial ${ }^{4}$ para a Igreja Católica, estabelecendo ainda um rigoroso controle sobre toda a actividade da Igreja" (História de Moçambique, 1999, p. 118).

Linden (1975, p. 30) nota que "o encontro entre o cristianismo e as religiões tradicionais tem muitas vezes tomado a forma de confrontação, motivada pelos ritos de transição que definem o indivíduo e reafirmam os valores da sociedade inteira”. Os ritos de iniciação jogam um papel

4 Ensino destinado aos indígenas. 


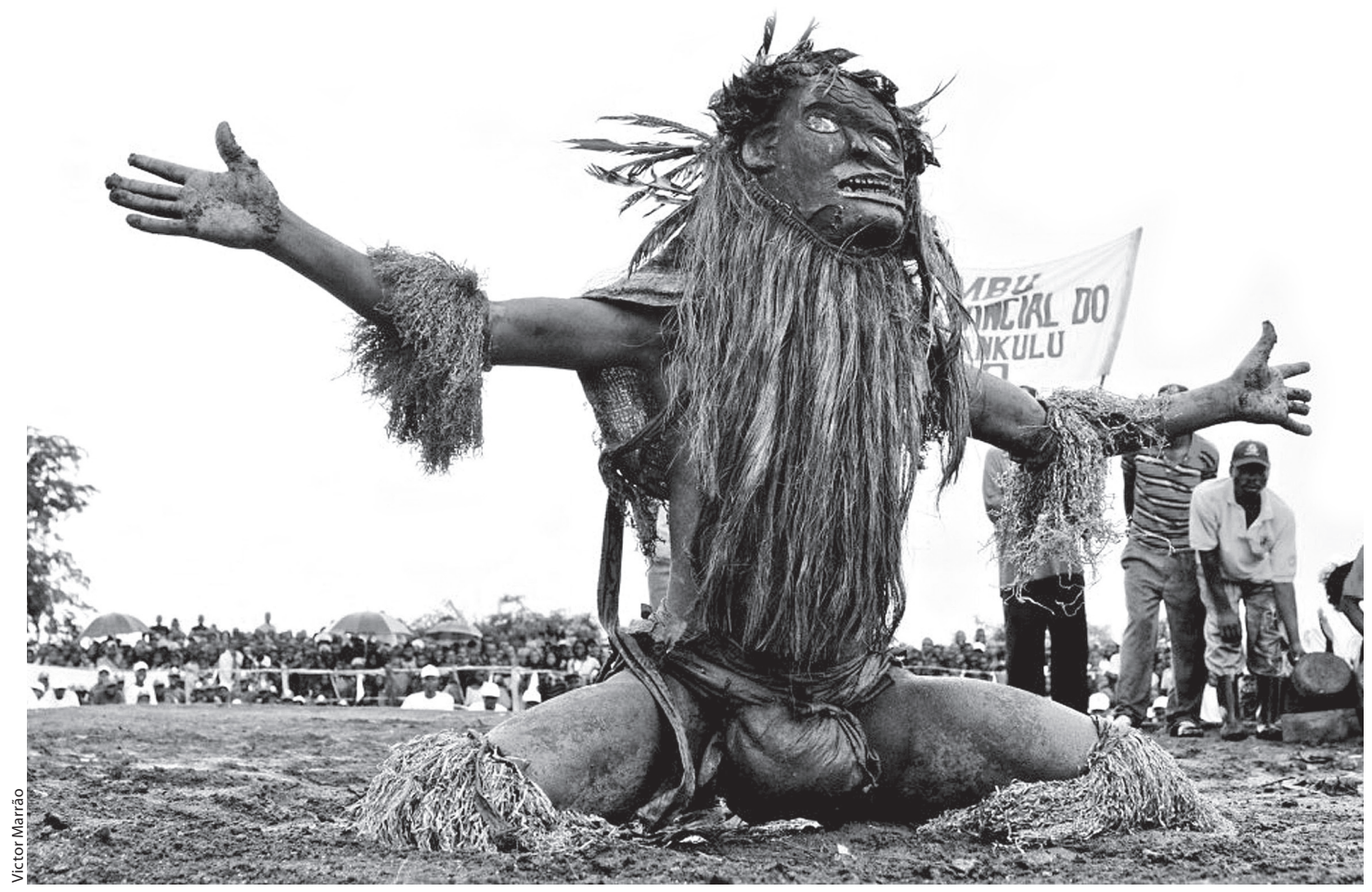

Máscara kampini exibindo-se num dos festivais de nyau na província de Tete

importante nas sociedades nyaus. É durante a iniciação no dambwe que os candidatos adquirem os valores, os costumes e as práticas do povo chewa, que se espera serem observados até a sua morte. Nesse contexto, a expansão da Igreja Católica, em Moçambique, resultou num conflito entre os missionários católicos e as sociedades nyaus. Alguns exemplos mais comuns desse relacionamento de intolerância e hostilidade são as agressões aos dançarinos, encorajadas pelos padres, o incitamento, pelos mesmos, ao roubo e à destruição de máscaras, disparos na arena de dança, bwalo, para intimidar e afugentar os assistentes. Além disso, algumas vezes, os missionários católicos pediam aos administradores coloniais que enviassem os sipaios $^{6}$ para prenderem e chicotearem os praticantes e depois mandá-los para o trabalho forçado. Como descreve o inquérito dos Serviços de Informação e

5 Lugar onde os membros do nyau fazem a iniciação dos candidatos e confeccionam as máscaras e os trajes.

6 Uma espécie de policiais indígenas que trabalhavam na administração colonial. Os sipaios se subordinavam diretamente aos capatazes brancos.
Coordenação de Informações da Polícia Internacional e de Defesa do Estado (Pide) ${ }^{7}$ :

"Não resistimos a referir que, no desenvolvimento do clima de hostilidade contra o 'nyau', tem desempenhado papel preponderante o Padre José João, da missão de S. Miguel Arcanjo do Chiritsi, na Macanga, autor da exposição que está na origem do nosso inquérito. Devemos aludir à péssima impressão que esse missionário nos causou, com toda a sua rasteira ignorância e dura intolerância, com todo o seu ódio irracional e doentio contra as atividades de 'nyau'. Publicamente se vangloria das violências que tem cometido contra os membros da irmandade quando os surpreende nas suas atividades rituais: assaltos contra os 'dambwe', agressões contra os mascarados, incitamento ao roubo e à destruição de máscaras, tiros para o ar disparados no 'bwalo' para amedrontar e pôr em fuga os assistentes, etc." (Gabinete Central de Organização do I Festival Nacional de Dança Popular, 1978, p. 55).

7 A então polícia secreta portuguesa. 
Como se pode perceber a partir do inquérito dos Serviços de Informação e Coordenação de Informações, as autoridades coloniais, embora pressionadas pelos missionários católicos, toleraram inicialmente o nyau. Essa atitude complacente das autoridades portuguesas deveu-se a sua incompreensão sobre o real significado do nyau, interpretado como simbolizando "a condescendência e apreciação aos dirigentes coloniais e à ordem eclesiástica, bem como a hospitalidade destas comunidades" (Manjate, em fase de elaboração).

Entre as máscaras usadas pelos dançarinos encontravam-se:

- Simione - imitava o colono, tendo o corpo pintado de branco e máscara da mesma cor;

- Makombe - imitava o militar colonial, com uma máscara avermelhada, vestuário europeu e um lenço servindo de bandeira atado na ponta de um pau comprido;

- Manuel - imitava o cantineiro colono;

- Maria - imitava a figura de colona, com grandes seios pendentes (António, em fase de elaboração).

Os dançarinos do nyau entretinham os visitantes importantes da administração colonial, a quem os administradores queriam agradar mostrando os costumes gentílicos e primitivos praticados pelos indígenas sob a sua jurisdição. Uma vez que os chewas dançavam de corpo nu, as autoridades portuguesas, no intuito de "civilizar" o nyau, "pediram" que os dançarinos cobrissem a região dos órgãos genitais e do traseiro. Como alternativa, os dançarinos passaram a usar saiotes que ainda hoje fazem parte das suas vestes.

Quando as autoridades coloniais perceberam que as figuras e os símbolos do nyau eram uma forma de resistência contra a sua presença, o nyau passou a ser violentamente reprimido. Um relatório da Pide chama atenção para as motivações políticas do nyau propondo a sua proibição:

“1. Na informação no 66-SC/CI (2)... vem a Polícia Internacional e de Defesa do Estado transcrever uma informação recebida na sua Delegação em Moçambique, subordinada ao título 'Uma perigosa sociedade secreta: o nyau' e na qual, depois de várias considerações e referências concretas, se termina por dizer que 'importa não esquecer a gravidade política do nyau'.

2. Diz, em resumo, a informação em apreço:

2.1. que o nyau é uma das sociedades secretas tão frequentes entre populações africanas, constituindo ameaça 'à civilização, ao Cristianismo e à soberania de Portugal' nas regiões da parte norte do distrito de Tete ocupados por povos acheuas (chipetas e azimbas);

2.2. que, à sombra das ideias segundo as quais constitui uma simples dança ou uma organização religiosa tradicional, o nyau tem frequentemente conseguido a complacência das autoridades, ampliando as suas atividades e propiciando a prática de crimes;

2.3. que o nyau parece ter estado relacionado com o culto dos mortos, mas degenerou na prática corrente de bacanais, bebedeiras coletivas e tem 'sobretudo a função de aliciar as massas', em ordem a manter, embora ocultamente, 'o primitivismo mais bárbaro nas instituições e na vida social da população autóctone', como consequência, o nyau constitui instrumento de oposição à civilização e cultura, ao mesmo tempo que impulsiona o ódio ao branco e fomenta o racismo negro;

2.4. que, assim, o nyau torna-se perigoso pela possível aliança com seitas religiosas - como as 'testemunhas de Jeová', já bastante ativas no distrito - a exemplo do que teria acontecido no Congo;

2.5. que o nyau é, no fundo, uma 'facção política', visto:

- manifestar vontade decidida de dominar toda a população;

- promover a concentração de milhares de pessoas fanatizadas;

- rodear-se de segredo rigoroso;

- propiciar a impunidade de crimes;

- exercer ilegitimamente a autoridade (cobrando impostos e impondo multas);

2.6. e que, em conclusão, os maiorais do nyau pretendem refugiar-se nas aparências de folclore para obterem a referida complacência das autoridades e, assim, incrementarem a sua ação, impondo-se a proibição definitiva de tais actividades" (Pide apud Gabinete Central de Organização do I Festival Nacional de Dança Popular, 1978, pp. 1-3).

Inicialmente reduzido pelo olhar colonial a uma forma folclórica de dança, o nyau foi pos- 
teriormente reduzido, pelo mesmo olhar, a um agrupamento político. Num novo contexto, caracterizado por uma forte repressão das autoridades coloniais, os praticantes do nyau foram obrigados a esconder-se, passando a dançar secretamente nas matas.

\section{NYAU DEPOIS DA INDEPENDÊNCIA}

Alcançada a independência, era necessário criar uma nação. O projeto de criação de uma nação do Rovuma ao Maputo implicava uma homogeneidade cultural, isto é, um conjunto de significados e valores compartilhados, memórias e símbolos. Samora Machel (1979, p. 12) defendia que "a grande questão central é a cultural". Nesse sentido, era imperioso romper com as culturas tradicional e colonial de forma a se criar uma cultura nacional e revolucionária. Em relação à educação tradicional, Machel defendia que era importante acabar com a educação tradicional porque a maior parte dos moçambicanos tinha passado por esse sistema que objetivava "transmitir a tradição, erigida em dogma que se perpetuaria através dos sistemas de classe, dos grupos de idade (opondo jovens e velhos), dos ritos de iniciação, da poligamia (que condenaria a mulher a um papel subordinado)" (Macagno, 2009, p. 21). No que tange ao sistema de educação colonial, Machel (1978, p. 10) argumentava que este tinha como objetivo transformar o moçambicano num "pequeno português de pele preta", referindo-se aos assimilados, um pequeno grupo de moçambicanos que habitava principalmente nas zonas urbanas e que teve acesso à educação colonial. Conforme notou Serra (1997, p. 102), "muitas componentes culturais do passado e do presente não escapam à esquadria da nova moral: hábitos, vestuário, liberdade sexual, jogo de azar, bailes, etc.".

Na Reunião Nacional de Cultura, em 1977, os participantes reconheceram que as danças constituíam um patrimônio cultural de grande valor, porém, defendiam "a extinção dos aspectos negativos, dos mitos irracionais, dos ritos e tabus supérfluos, de modo a se conservar e manter como valor cultural inestimável" (Tempo, 1977, p. 32). Aparentemente, algumas práticas do nyau consideradas retrógradas pelos dirigentes do partido-governo da Frelimo continuaram a pre- valecer. Os membros do nyau continuaram a agir de forma violenta com mulheres e homens não iniciados que se aproximavam do bwalo, assim como sobre os iniciados que demonstravam mau comportamento durante os ritos. As entrevistas que realizei na província de Tete, no distrito de Chiúta, permitem-me concluir que esse comportamento violento, que algumas vezes resultava em mortes, se estendeu até um pouco depois da proclamação da dança nyau como obra-prima do patrimônio oral e intangível da humanidade. Os praticantes do nyau afirmaram que apenas os policiais iniciados é que podiam intervir em casos de conflitos entre eles, mas apenas quando solicitados. Como resultado da agressividade dos praticantes, vários iniciados acabaram se refugiando nos países vizinhos, como Zâmbia, Zimbábue e Malawi. Portanto, em várias povoações onde o nyau era praticado, as sociedades nyau continua-

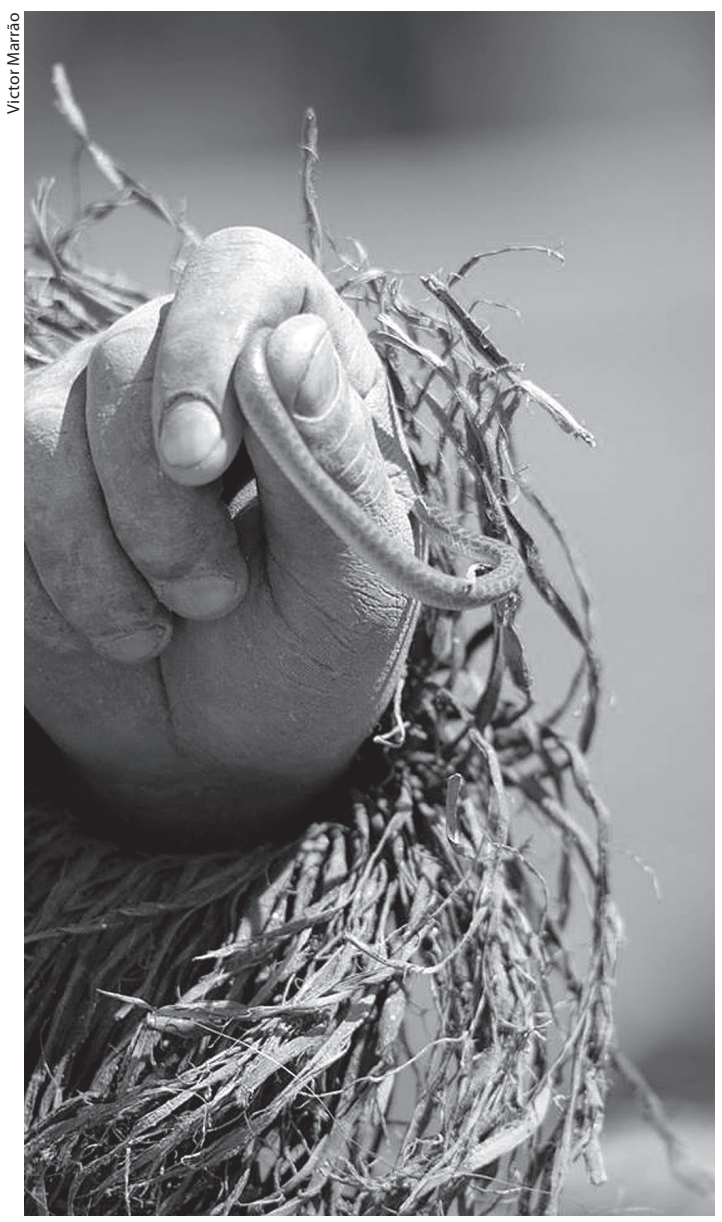

Mão de dançarino de nyau segurando um filhote de cobra, simbolizando a continuidade 
ram a ser a única instituição responsável pela educação das crianças. Parece que o nyau tinha ainda algum poder em âmbito local.

Em 1978 foram introduzidos os festivais nacionais de cultura. O primeiro festival realizado na cidade de Maputo, capital do país, recebeu a designação de Festival Nacional de Dança Popular. O objetivo desses festivais era a criação do patrimônio moçambicano através da integração das diversas danças regionais existentes no país.

É útil destacar aqui que nesse processo de transformação das diversas manifestações culturais em patrimônio nacional foi enfatizada a dimensão política através da construção de uma narrativa que ligava a sua emancipação do jugo colonial à luta armada de libertação nacional dirigida pela Frelimo. Como nos ensinou Trajano Filho (2010, p. 38), "patrimonializar é fazer escolhas: dos artefatos a serem objetivados, de seu significado para a nação ou para as culturas locais e das versões acerca de sua história". No caso do nyau, por exemplo, o Gabinete Central de Organização do I Festival Nacional de Dança Popular (1978, p. 56) narra que:

"Na altura do início da Luta Armada que iria pôr fim ao regime colonial, a Pide procura proibir o nyau considerando-o uma 'seita muito perigosa contra a soberania portuguesa'. No entanto a luta anticolonial não se podia realizar com sucesso no quadro regional que era dado pelo nyau. O trabalho de mobilização política, entretanto, desenvolvido pela Frelimo, vai a partir daí canalizar a luta desenvolvida pelos nyaus, numa luta mais geral, desenvolvida em nível nacional, como única forma possível de se obter a Independência de Moçambique".

\section{O NYAU COMO PATRIMÔNIO DA HUMANIDADE}

Em 25 de novembro de 2005, o nyau foi proclamado obra-prima do patrimônio oral e intangível da humanidade. A entrega do certificado da Unesco ocorreu em 2007, na vila de Ulongué, sede do distrito de Angónia, com a presença do então presidente da República de Moçambique, Armando Guebuza,e representantes dos governos do Malawi e da Zâmbia.
De acordo com a Unesco, "a inscrição de um bem seleccionado será diferida até que o Estado proponente faça provas do seu empenho em proteger esse bem. Esse empenhamento pode tomar a forma de legislação, de atribuição de pessoal, de financiamentos e de um plano de gestão"8. Procurando cumprir com essa cláusula dos "procedimentos para apresentação de candidaturas" da Unesco, o projeto de candidatura do Malawi, da Zâmbia e de Moçambique apresentou um plano de ação de cinco anos, visando à preservação e divulgação do nyau, tanto nacional como internacionalmente.

Em Moçambique, o governo declarou que o nyau e a timbila ${ }^{9}$ passariam a ter acesso direto à fase final dos festivais nacionais de cultura, estando assim isentos das eliminatórias, disputadas no âmbito provincial. Para além da sua presença nesses festivais, os grupos de nyau têm participado também em festivais regionais ${ }^{10} \mathrm{e}$ internacionais. Frequentemente, o nyau tem sido convidado pelas instituições governamentais para abrilhantar as celebrações dos feriados nacionais, com destaque para os dias 25 de junho (Dia da Independência), 7 de setembro (Dia da Vitória) e 25 de setembro (Dia das Forças Armadas). Em junho de 2014, a dança foi distinguida com a Medalha Bagamoyo pelo então presidente da República de Moçambique, Armando Guebuza. Esse título honorífico foi estabelecido pela Lei no ${ }^{\mathrm{o}}$ 10/2011, de 13 de julho - lei sobre o sistema de títulos honoríficos e condecorações, que, aprovada pela Assembleia da República com o voto majoritário da bancada da Frelimo, inclui ainda outras distinções como: Herói da República Popular de Moçambique; Ordem Samora Machel, do $1^{\circ}$ e $2^{\circ}$ graus; Ordem 25 de Junho; Ordem Militar 25 de Setembro, do 2o grau; Ordem 4 de Outubro, do $1^{\circ}$ e $2^{\circ}$ graus; Medalha Veterano da Luta de Libertação de Moçambique. Cabe lembrar que o Centro de Bagamoyo, na Tanzânia, foi um

8 Disponível em: http://www.unesco.org. Acesso em: 15 de janeiro de 2013.

9 Tal como o nyau, a timbila também foi proclamada obra-prima do patrimônio oral e intangível pela Unesco. Porém, diferentemente da candidatura do nyau, a candidatura da timbila foi apresentada de forma individual pelo governo de Moçambique.

10 Esses festivais envolvem apenas os três países que praticam o nyau. 
centro de preparação político-militar da Frelimo durante a luta armada de libertação nacional.

Entretanto, os membros do governo aparentam ter uma atitude ambígua em relação ao nyau. $\mathrm{O}$ anterior ministro da Educação e Cultura, Aires Ali, intervindo no seminário de reflexão sobre o nyau, realizado em Ulongué, distrito de Angónia, afirmou que "o segredo é bom quando nos protege, mas é muito mau e fútil quando se vira contra nós ou está contra o nosso progresso" "1. A fala de Aires Ali parece demonstrar uma tentativa de disciplinamento das sociedades secretas nyaus, que durante muito tempo preservaram o seu poder em âmbito local.

Para além de abrilhantar as comemorações oficiais, a dança nyau tem sido também "performatizada" em festivais organizados por empresas públicas. Em Tete, as performances públicas do nyau são acompanhadas de exposições organizadas pelas instituições de cultura, em que são apresentados os diversos materiais usados pelos dançarinos do nyau, como, por exemplo, máscaras, saiotes, chocalhos, batuques, mbira, etc. O delegado do Arquivo de Patrimônio Cultural (Arpac), em Tete, afirmou que estava prevista a construção de um museu do nyau na localidade de Manje, distrito de Chiúta.

Um aspecto que despertou a minha atenção durante a conversa com o diretor provincial adjunto de cultura de Tete, Jacob Zimba, foi a possível apropriação da dança nyau pela cultura de massas. Zimba afirmou que existe em Tete um grupo de dançarinos do nyau denominado kandaba. Na fala desse dirigente "o kandaba não é original. É uma imitação do nyau. Os seus praticantes nem sequer passaram pelos ritos de iniciação" (informação verbal).

Tal como Trajano Filho observou ao analisar as mandjuandades e as tabancas, a dança nyau está se transformando num espetáculo artístico e cultural, relegando-se para um plano inferior os complexos rituais associados ao nyau, a lógica interna ligada aos membros e suas atividades, e sua cosmologia. Há uma percepção do público externo de que, no período pós-patrimônio da hu-

11 Disponível em: http://www.mozambique-music.com/ sites/pages/articles/mmm049_noticias.htm. manidade, as apresentações do nyau estão mais viradas para o entretenimento de turistas e para fins políticos, esvaziando-se gradualmente a sua função original e significados.

É interessante notar que a concentração e a performance dos dançarinos são feitas em contextos espaciais muito diferentes do liwunde $e^{12} \mathrm{e}$ do bwalo. $\mathrm{O}$ nyau, exibido agora em palcos montados e quadras esportivas, é presenciado predominantemente por um público não iniciado. Aliás, para além da presença de membros do governo, é grande o número de turistas que afluem a esses festivais, ávidos por assistir e registrar com as suas filmadoras as performances dos dançarinos do nyau.

Num dos pontos do seu manual de "procedimentos para apresentação de candidaturas" a patrimônio mundial, a Unesco declara que, "sempre que um bem tenha sofrido uma deterioração que implique a perda das características que determinaram a sua inscrição na Lista do Património Mundial, aplicar-se-á o procedimento relativo à sua eventual exclusão da Lista" ${ }^{13}$. Assim, ancorada nos critérios de excepcional valor universal e risco de desaparecimento, a Unesco recomendou aos três países proponentes da candidatura do nyau a patrimônio da humanidade que organizassem regularmente festivais como forma de preservação e divulgação dessa manifestação cultural. Isso implica que os dançarinos do nyau exibam as suas performances fora dos seus contextos tradicionais e para um público não iniciado, o que é uma redução de sentido. O discurso da Unesco, ao enfatizar a divulgação e a preservação da dança nyau, reduz, paradoxalmente, o seu sentido.

Nas entrevistas realizadas em Chiúta, os praticantes do nyau reconheceram a mudança nas suas atividades depois da chancela da Unesco, contudo, isso parece não significar um esmorecimento da dimensão religiosa, ritual e cosmológica ligada às sociedades nyaus, pois, conforme garantiram, "não se perde o segredo. O segredo está lá, guardado no mato" ${ }^{14}$. Como afirmaram:

12 Lugar onde os dançarinos se concentram antes da dança.

13 Disponível em: http://www.unesco.org. Acesso em: 15 de janeiro de 2013.

14 Cemitério onde são guardados os fardamentos e as máscaras usadas pelos praticantes do nyau. 
"Antes dançávamos nos ritos de iniciação, funerais e casamentos, mas, agora, dançamos também nas reuniões do governo, datas festivas como 25 de Junho, 25 de Setembro. Mas sábado e domingo costumamos tocar batuque e dançar longe. Só pode assistir quem foi iniciado. Se for descoberto alguém a assistir sem que seja iniciado, essa pessoa é batida. Este tipo de situações nem a polícia resolve" (grupo de praticantes do nyau no distrito de Chiúta).

A fala acima demonstra a existência de um nyau com dois sentidos: um, com um caráter mais secreto, virado para os seus rituais mais importantes, e outro, mais voltado ao espetáculo, para abrilhantar as comemorações cívicas, festivais e celebrações diversas.

O delegado do Arpac de Tete conta que antes do início do festival da Argélia, para onde tinha sido convidado um grupo de nyau da província de Tete, estava marcada uma exposição. Os dirigentes pediram que o grupo enviasse o seu material para a Argélia antes da viagem, de modo que pudesse ser apresentado na exposição. O grupo recusou perguntando: "Como é que as armas vão primeiro que os soldados?" (Manjate, informação verbal). Referindo-se às viagens feitas com os grupos de nyau à Argélia e à França, o diretor provincial de cultura de Tete afirmou:

"Na Argélia havia palcos montados, mas montaram palcos especiais para nós. Foram buscar caminhões com terra para o nyau dançar lá. Tivemos que arranjar um bananal, pois eles se recusaram a se vestir nos camarins. Os dançarinos não aceitam. Em Paris, por exemplo, sem avisar, saíram com os seus equipamentos. No hotel havia um bananal. Eles dirigiram-se para o bananal e usaram as máscaras. Esses dançarinos foram interpelados pela polícia, que achava que eram terroristas, e de dois deles foram retiradas as máscaras e o grupo recusou-se a ir atuar. A sua participação no festival só foi possível depois de delicadas negociações com as autoridades francesas e com os organizadores do festival" (Zimba, informação verbal).

O nyau foi objetificado pelo Estado como patrimônio cultural moçambicano e pela Unesco como patrimônio imaterial da humanidade. Contudo, esses exemplos revelam que, apesar da redução de sentido, os praticantes do nyau estão continuamente negociando os seus interesses, tanto nas exposições, como nas várias atividades que têm abrilhantado.

\section{BIBLIOGRAFIA}

ANTÓNIO, A. O Papel do Nyau no Desenvolvimento do Turismo Transfronteiriço (em fase de elaboração).

ARPAC - Instituto de Investigação Sociocultural. Por uma Investigação que Valorize a História e Cultura Moçambicana. Disponível em: http://issuu.com/arpaccentral/docs/ historia_do_arpac.

BUUR, Lars; KYED, Helene. "Contested Sources of Authority: Re-claiming State Sovereignty by Formalizing Traditional Authority in Mozambique", in Development and Change, n. 37 (4), 2006, pp. 847-69.

DOVE, Roberto. Informação verbal. [15 de janeiro, 2013], Maputo.

GABINETE CENTRAL de Organização do I Festival Nacional de Dança Popular, 1978. GRUPO DE PRATICANTES do Nyau do Distrito de Chiúta. Entrevista [12 de agosto, 2011], Distrito de Chiúta. 
HISTÓRIA DE MOÇAMBIQUE. v. 2. Moçambique no Auge do Colonialismo, 1930-1961. Maputo, Livraria Universitária, 1999.

LINDEN, lan. "Chewa Initiation Rites and Nyau Societies: the Use of Religious Institutions in Local Politics at Mua", in T. Ranger; John Weller. Themes in the Christian History of Central Africa. London, Heinemann, 1975.

MACAGNO, Lorenzo. "Fragmentos de uma Imaginação Nacional", in Revista Brasileira de Ciências Sociais, v. 24, n. 70, 2009, pp. 18-35.

MACHEL, Samora. “Educar o Homem para Vencer a Guerra, Criar uma Sociedade Nova e Desenvolver a Pátria", in Departamento de Trabalho Ideológico. Maputo, Frelimo, 1978. "A Grande Questão Central É a Cultural", in Tempo, n. 431, 1979.

MALAWI National Commission for Unesco. Candidature File on Cultural Expressions Around Nyau Traditions.

MANJATE, Fernando. Informação verbal. [14 de janeiro, 2013], Maputo.

Nyau-Gule Wamkulu: a Grande Dança. Maputo, Arpac- Instituto de Investigação Sociocultural (em fase de elaboração).

"RELATÓRIO do Comité Político Permanente à IV Reunião do Comité Central do Partido Frelimo", in Tempo, n. 508, 1980.

SERRA, Carlos. Novos Combates pela Mentalidade Sociológica. Maputo, Livraria Universitária, 1997.

TRAJANO FILHO, W. "Patrimonialização dos Artefatos Culturais e a Redução dos Sentidos", in Lívio Sansone (org.). Memória da África: Patrimônios, Museus e Políticas das Identidades. Brasília, ABA Publicações, 2010.

ZIMBA, Jacob. Informação verbal. [6 de janeiro, 2013], Tete. 